REVIEW

\title{
Muscle dysfunction versus wear and tear as a cause of exercise related osteoarthritis: an epidemiological update
}

Ian Shrier

Br J Sports Med 2004;38:526-535. doi: 10.1136/bjsm.2003.011262

There are two main hypotheses for the cause of exercise related osteoarthritis: wear and tear of the articular cartilage and muscle dysfunction. This is a review of the clinical literature to see which hypothesis has the greatest support. Clinical studies support the muscle dysfunction hypothesis over the wear and tear hypothesis.

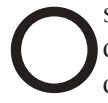
steoarthritis (OA) often limits activities of daily living-for example, climbing stairs, dressing ${ }^{1}$ - and can prevent participation in the labour force for younger patients. ${ }^{1}$ Patients seek advice from family doctors, internists, rheumatologists, and orthopaedic surgeons.

Recently sponsored symposia in both the United States ${ }^{2}$ and Canada (co-sponsored by the Canadian Institutes of Health Research and the Canadian Arthritis Network, Toronto, Ont, April 2002) suggest that OA is a complex syndrome-that is, constellation of symptoms and signs with multiple causes - that involves the balance between cartilage synthesis and degradation, and affects all tissues surrounding the joint. That being said, the question remains as to which factors are directly related to the cause of OA and are modifiable so that doctors may counsel patients appropriately.

In the case of primary OA-that is, excluding genetic diseases, severe biomechanical abnormalities, post-septic arthritis, etc-many healthcare professionals believe the major cause of OA is "wear and tear" - that is, gradual thinning of the articular cartilage due to repeated weight bearing activity of the joints-and that therefore $\mathrm{OA}$ is caused and worsened by exercise. However, in 1999, Hurley ${ }^{3}$ reviewed the basic science evidence and proposed that properly contracting muscles are the main force absorber for the joint, and that muscle dysfunction is the most important modifiable mediating factor for primary OA. Because regular exercise improves muscle function, this hypothesis predicts that exercise would not increase the incidence of or worsen OA. Hurley also suggested that whereas the wear and tear hypothesis predicts that cartilage thinning will be the first sign of OA, the muscle dysfunction hypothesis predicts that sclerosis would be the first sign. Finally, in the case of injury, the muscle dysfunction hypothesis predicts that injuries to muscles in a leg may increase the risk of $\mathrm{OA}$ in joints not immediately adjacent to the injured muscle because impact forces are not being properly absorbed. The wear and tear hypothesis suggests that injuries would only increase the risk of OA if articular cartilage injury occurs at the time of injury, or is more likely to occur after injury-for instance, anterior cruciate ligament (ACL) instability. The specific objective of this systematic review is to determine the clinical evidence in support of and against the hypotheses that exercise related OA is caused by $(a)$ wear and tear or $(b)$ muscle dysfunction.

The reader should not forget that $\mathrm{OA}$ is multifactorial and that there are other causes of OA. As such, there are two important limitations to the scope of this article. Firstly, it focuses on both hip and tibiofemoral OA and does not discuss patellofemoral OA, or OA in other areas of the body. Secondly, regardless of the initiating event of OA in a particular patient, the articular cartilage is eventually destroyed. The mechanism of articular cartilage destruction is also beyond the scope of this article.

\section{MATERIALS AND METHODS}

A systematic review of the literature was carried out. Medline and SportDiscus databases were searched using the strategy (osteoarthritis or osteoarthrosis) AND (activity or exercise or injury). Based on titles and abstracts, all potentially pertinent articles were retrieved and reviewed. The bibliographies of all articles retrieved were reviewed for additional references, and a search of Citation Search Index was conducted to find any article that may have cited one of the key articles previously retrieved. Data were abstracted by one person using a standardised form, and verified with a second reading by the same person at least four weeks later. This review is limited to exercise related primary OA, and studies investigating OA secondary to injury or previous surgery were not included in the results.

Results are presented as odds ratios (OR) or relative risks (RR) or hazard ratios (HR) with 95\% confidence intervals (95\%CI) in parentheses unless otherwise specified. Because many studies lacked the necessary power to determine if the differences were statistically significant, relying on $\mathrm{p}$ values or confidence intervals might result in a $\beta$ error (incorrectly indicating that the differences between groups were not important). Therefore, the emphasis in this review is on the

Abbreviations: $O A$, osteoarthritis; OR, odds ratios; $R R$, relative risk; $\mathrm{HR}$, hazard ratio; $95 \% \mathrm{Cl}, 95 \%$ confidence intervals; $\mathrm{ACL}$, anterior cruciate ligament; Exp, exercise group; Con, control group 
direction and magnitude of the changes-that is, are the changes clinically relevant?- rather than whether a study had significant results.

Because the clinical studies reported different outcomes, used widely differing methodology, etc, a qualitative synthesis was more appropriate than an attempt to provide an overall summary statistic for the estimate of the effect.
RESULTS

Twenty three clinical articles (representing 18 studies) related to exercise and OA were retrieved. Table 1 presents studies on running, table 2 presents studies on football, and table 3 presents studies on other sports. Where studies reported on more than one type of exposure, the relevant details are repeated under each section and the duplication noted.

Table 1 Details of studies related to running exposure $(95 \% \mathrm{Cl}$ in parentheses)

\begin{tabular}{|c|c|c|c|c|c|c|}
\hline \multirow{2}{*}{\multicolumn{7}{|c|}{$\begin{array}{l}\text { Article } \\
\text { Exercise associated with OA }\end{array}$}} \\
\hline & & & & & & \\
\hline \multirow{6}{*}{$\begin{array}{l}\text { Marti }^{16} \\
(n=59)\end{array}$} & \multirow{6}{*}{$\begin{array}{l}\text { Males, age range not reported. } \\
\text { Exp: } 27 \text { ex-elite long-distance } \\
\text { runners and } 9 \text { bobsleigh from } \\
1973 \text {. } \\
\text { Con: } 23 \text { untrained men from } \\
\text { "randomised training study" in } \\
1973 \text {. }\end{array}$} & \multirow{6}{*}{$\begin{array}{l}\text { Historical cohort with } \\
15 \text { yrs follow-up. } \\
\text { Information obtained by } \\
\text { recall. } \\
\text { Blinded assessment of X- } \\
\text { rays. } \\
\text { Follow-up in } 1988 \text {. }\end{array}$} & \multicolumn{3}{|c|}{ Mean values } & \multirow{6}{*}{$\begin{array}{l}\text { Response rate } 27 / 27 \text { runner, } 9 / 12 \text { bobsleigh } \\
\text { and } 23 / 26 \text { controls. } \\
\text { OA scored separately as joint space, sclerosis } \\
\text { and osteophytes, and also as a composite } \\
\text { score ranging from } 0-9 \text {. } \\
\text { Although composite score worse for runners, } \\
\text { the mean score was only } 1.4 \text { of a total score } \\
\text { of } 9 \text {. Still, } 4 / 27 \text { runners had joint space } \\
<3 \mathrm{~mm} \text { whereas there were no bobsleigh or } \\
\text { control subjects with this limited amount of join } \\
\text { space. }\end{array}$} \\
\hline & & & & Joint space & $\begin{array}{l}\text { Composite knee } \\
\text { score }\end{array}$ & \\
\hline & & & Runners & $3.8(3.4$ to 4.2$)$ & $1.4(0.8$ to 2.0$)$ & \\
\hline & & & Bobsleigh & $4.7(4.1$ to 5.2$)$ & $0.3(-0.05$ to 0.7$)$ & \\
\hline & & & Control & $4.0(3.6$ to 4.4$)$ & $0.3(0.0$ to 0.6$)$ & \\
\hline & & & $\begin{array}{l}\text { Grade } 2 \text { sub } \\
\text { present in ru } \\
\text { Running pac } \\
\text { OA. } \\
\text { Hip pain wo } \\
\text { bobsleigh or }\end{array}$ & $\begin{array}{l}\text { chondral sclerosis and } \\
\text { iners. } \\
\text { was a better predicto } \\
\text { s present in } 30 \% \text { of the } \\
\text { control groups. }\end{array}$ & $\begin{array}{l}\text { osteophytes only } \\
\text { runners, but } 0 \% \text { of }\end{array}$ & \\
\hline \multirow[t]{11}{*}{$\begin{array}{l}\text { Cheng }^{17} \\
(n=16961)\end{array}$} & \multirow{8}{*}{$\begin{array}{l}\text { Males }(n=12888 \text { and } \\
\text { females }(n=4073) \text {. } \\
\text { Ages } 20-87 \text {. } \\
\text { Exp: Low }=\text { walk or jog }<10 \\
\text { miles } / w k(n=3006) \text { males, } \\
1029 \text { females), Mod = walk or } \\
\text { jog } 10-20 \text { miles } / w k \text { ( } n=1760 \\
\text { males, } 495 \text { females), High }=\text { walk } \\
\text { or jog }>20 \text { miles } / w k \text { ( } n=1003 \\
\text { males, } 211 \text { females). Other } \\
\text { category ( } n=2846 \text { males, } 1042 \\
\text { females) not included in this } \\
\text { report. }\end{array}$} & \multirow{3}{*}{$\begin{array}{l}\text { Historical cohort with } \\
\text { mean (SD) follow-up time } \\
\sim 10(6) \text { yrs. } \\
\text { Information obtained by } \\
\text { survey. }\end{array}$} & $\begin{array}{l}\text { Hazard ratic } \\
\frac{\text { alcohol, smc }}{\text { sedentary). }}\end{array}$ & $\begin{array}{l}\text { s for self-reported OA } \\
\text { king, caffeine (referenc }\end{array}$ & $\begin{array}{l}\text { adjusted for } B M I, \\
\text { e category }=\end{array}$ & \multirow{11}{*}{$\begin{array}{l}\text { The inclusion of people as young as } 20 \text { for an } \\
\text { outcome of OA may be inappropriate. The } \\
\text { mean follow-up time suggests skewed } \\
\text { distribution and we are not sure of minimum } \\
\text { follow-up time. } \\
\text { Some subjects in mod or high categories may } \\
\text { have been walkers instead of runners. } \\
\text { There was another category of "Other" } \\
\text { referring to activity that is not walking or } \\
\text { jogging. This was omitted in this review } \\
\text { because details of the activity were not } \\
\text { reported. } \\
\text { Although results not significant for women, } \\
\text { there does appear to be some association for } \\
\text { young men involved in high levels of activity. } \\
\text { However, this is not true for older men, } \\
\text { suggesting that it is not simply the activity that } \\
\text { is the problem. }\end{array}$} \\
\hline & & & & Males & Females & \\
\hline & & & \multicolumn{3}{|c|}{$<50$ yrs old } & \\
\hline & & \multirow{8}{*}{$\begin{array}{l}\text { Self-reported exposure } \\
\text { and outcome so no } \\
\text { blinding. }\end{array}$} & Low & $1.0(0.6$ to 1.5$)$ & $0.8(0.8$ to 1.6$)$ & \\
\hline & & & Mod & $1.2(1.0$ to 1.4$)$ & $1.2(1.2$ to 1.5$)$ & \\
\hline & & & High & $2.4(1.5$ to 3.9$)$ & $1.5(1.5$ to 5.1$)$ & \\
\hline & & & $>50$ yrs ol & & & \\
\hline & & & Low & $1.3(0.9$ to 1.8$)$ & $0.6(0.3$ to 1.2$)$ & \\
\hline & \multirow{3}{*}{$\begin{array}{l}\text { Control: sedentary }(n=4273 \\
\text { males, } 1296 \text { females). }\end{array}$} & & Mod & $1.0(0.8$ to 1.2$)$ & $1.2(0.9$ to 1.5$)$ & \\
\hline & & & High & $1.2(0.6$ to 2.3$)$ & $1.4(0.4$ to 4.6$)$ & \\
\hline & & & & & & \\
\hline \multirow[t]{10}{*}{$\begin{array}{l}\text { Spector }^{18} \\
(n=1058)\end{array}$} & \multirow{10}{*}{$\begin{array}{l}\text { Women, ages } 40-65 \text {. } \\
\text { Exp: ex-elite runners (middle and } \\
\text { long distance) and tennis players } \\
(n=81) \\
\text { Con: General population survey } \\
(n=977) \text {. }\end{array}$} & \multirow{10}{*}{$\begin{array}{l}\text { Historical cohort } \\
\text { (15-45 yr follow-up). } \\
\text { OA status by x-ray and } \\
\text { exposure status by } \\
\text { recall. } \\
\text { Blinding not reported. }\end{array}$} & \multicolumn{3}{|c|}{$\begin{array}{l}\text { OR for elite vs controls for different joints (adjusted for } \\
\text { age, height and weight). }\end{array}$} & \multirow{10}{*}{$\begin{array}{l}\text { Response rate } 81 / 117 \text { elite athletes and } \\
977 / 1003 \text { controls. } \\
\text { Adequate information on physical activity in } \\
\text { controls available in only } 585 / 977 \text { controls. } \\
\text { OA assessed by joint space narrowing and } \\
\text { osteophytes, but no total score. } \\
\text { Among the control population with differnt } \\
\text { levels of physical activity, the OR for joint } \\
\text { space narrowing among the people with a } \\
\text { past history of long-term physical activity was } \\
\text { close to that of the elite athletes. } \\
\text { The respective OR for osteophytes (among } \\
\text { controls) was much higher than that of joint } \\
\text { space narrowing. They were not reported here } \\
\text { for space limitations. Note that the importance } \\
\text { of osteophytes is not yet clear }{ }^{56} \text {. }\end{array}$} \\
\hline & & & & Osteophytes & Narrowing & \\
\hline & & & \begin{tabular}{|l} 
Tibio- \\
femoral
\end{tabular} & $3.6(1.9$ to 6.7$)$ & $1.2(0.7$ to 1.9$)$ & \\
\hline & & & $\begin{array}{l}\text { Patello- } \\
\text { femoral }\end{array}$ & $3.5(1.8$ to 6.8$)$ & $3.0(1.2$ to 7.7$)$ & \\
\hline & & & Hip & $2.5(1.0$ to 6.3$)$ & $1.6(0.7$ to 3.5$)$ & \\
\hline & & & \multicolumn{3}{|c|}{$\begin{array}{l}\text { OR for control women with a history of different levels of } \\
\text { physical activity (reference is low physical activity). Long } \\
\text { term }=\text { ">4 units/wk", Moderate }=" 1-3 \text { units/wk" }\end{array}$} & \\
\hline & & & & $\begin{array}{l}\text { Hip joint space } \\
\text { narrowing }\end{array}$ & $\begin{array}{l}\text { Tibio-femoral joint } \\
\text { space narrowing }\end{array}$ & \\
\hline & & & Long-ferm & $1.80(0.73$ to 3.48$)$ & $0.85(0.31$ to 2.04$)$ & \\
\hline & & & Moderate & $1.05(0.54$ to 2.12$)$ & $0.80(0.52$ to 1.08$)$ & \\
\hline & & & \multicolumn{3}{|c|}{$\begin{array}{l}\text { The OR point estimates are estimated from a figure but the } \\
\text { confidence intervals were exactly given. }\end{array}$} & \\
\hline \multirow{4}{*}{$\begin{array}{l}\text { Vingard }^{18} \\
\text { (n = 569) } \\
\text { The results of this study } \\
\text { related to soccer are } \\
\text { reported in table 2, } \\
\text { and the results related } \\
\text { to the total sport } \\
\text { participation are } \\
\text { reported in table } 3 \text {. }\end{array}$} & \multirow{4}{*}{$\begin{array}{l}\text { Males, ages } 50-70 . \\
\text { Cases: Total hip replacement } 2^{\circ} \\
\text { idiopathic OA in } 4 \text { Swedish } \\
\text { hospitals ( } n=247 \text { partial } \\
\text { participation, } 233 \text { partial } \\
\text { participation). } \\
\text { Controls: Swedish men living in } \\
\text { area of same } 4 \text { hospitals } \\
\text { (n=322 partial participation, } \\
302 \text { complete participation). }\end{array}$} & \multirow{4}{*}{$\begin{array}{l}\text { Case-contol. } \\
\text { Information by recall. } \\
\text { Blinding of evaluators for } \\
\text { exposure not reported. }\end{array}$} & \multicolumn{3}{|c|}{$\begin{array}{l}\text { RR for total hip replacement among runners, adjusted for } \\
\text { age, BMl, smoking and physical load at work. }\end{array}$} & \multirow{4}{*}{$\begin{array}{l}\text { Response rate } 233 / 253(92 \%) \text { for full } \\
\text { participation among cases, and } 302 / 392 \\
(72 \%) \text { among controls. Slightly greater partial } \\
\text { participation rates for both groups. } \\
\text { Relative risks estimated from OR. } \\
\text { Exposure information obtained by recall } \\
\text { during interview. Authors note that recall in } \\
\text { myocardial infarction patients and controls } \\
\text { found no increased RR and they suggest that } \\
\text { shows recall not a problem. However, if } \\
\text { regular physical activity is protective against } \\
\text { infarction, and recall not an issue, then } \\
\text { physical activity should have been protective. }\end{array}$} \\
\hline & & & & Medium & High & \\
\hline & & & $\begin{array}{l}\text { Long- } \\
\text { distance } \\
\text { runners }\end{array}$ & $1.7(0.4$ to 6.9$)$ & $2.1(0.6$ to 6.8$)$ & \\
\hline & & & \multicolumn{3}{|c|}{$\begin{array}{l}\text { Track \& field and racquet sports had highest RR }(\sim 2.4 \\
\text { for medium exposure and } \sim 3.5 \text { for high exposure) among } \\
\text { all sports. }\end{array}$} & \\
\hline
\end{tabular}


Table 1 Contd

Exercise not associated with OA

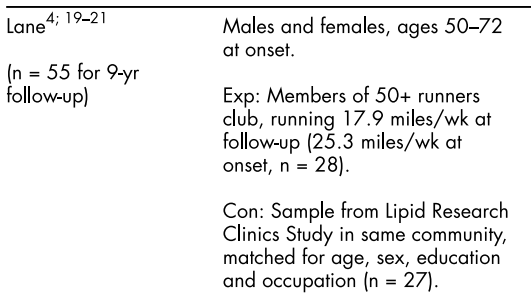

\begin{tabular}{|c|c|c|c|c|}
\hline \multirow{2}{*}{$\begin{array}{l}\text { Prospective cohort with } \\
9 \text {-yr follow-up. } \\
\text { Blinded assessment of } x- \\
\text { rays. }\end{array}$} & \multicolumn{4}{|c|}{$\begin{array}{l}\text { Change in } \mathrm{x} \text {-ray score (higher score means progression } 0 \\
\text { OA sign). }\end{array}$} \\
\hline & & Osteophytes & Joint space & $\begin{array}{l}\text { Total knee } \\
\text { score }\end{array}$ \\
\hline & \multicolumn{4}{|l|}{ Knee } \\
\hline & Runners & $0.80(0.23)$ & $0.20(0.10)$ & $0.96(0.28)$ \\
\hline & Non-runners & $0.67(0.32)$ & $0.32(0.12)$ & $1.03(0.42)$ \\
\hline & \multicolumn{4}{|l|}{ Hip } \\
\hline & Runners & $0.50(0.10)$ & $0.27(0.10)$ & $1.14(0.20)$ \\
\hline & Non-runners & $0.65(0.30)$ & $0.52(0.10)$ & $1.62(0.50)$ \\
\hline
\end{tabular}

Response rate: 43 subjects of original cohort $(n=98)$ followed for 9 years. No difference between group that returned and those that did not return.

OA graded osteophytes, joint space and sclerosis separately, and then composite score.

One paper was original cross-sectional analysis, followed by three papers published using the same subjects with 2, 5 and 9-yr usllow-up report. Results used are from the 9-yr follow-up report. Results at 5 years were qullow-up report. Results at 5 years were
qualitatively similar for the knee (hip results not presented prior to $9 \mathrm{yr}$ follow-up)

Changes in hip not significantly different between groups for any score, but non-runners had more knee joint space narrowing and fewer knee osteophytes than runners (total score not significantly different).

\begin{tabular}{|c|c|}
\hline Kujala $^{13-15}$ & Males, ages $21-86$. \\
\hline$(n=2059)$ & $\begin{array}{l}\text { Exp: } 1282 \text { ex-elite male athletes } \\
\text { from a wide variety of sports. }\end{array}$ \\
\hline $\begin{array}{l}\text { The results of this study } \\
\text { related to soccer are } \\
\text { reported in table 2, } \\
\text { and the results related } \\
\text { to overall sport are } \\
\text { reported in table } 3 \text {. }\end{array}$ & $\begin{array}{l}\text { Con: } 777 \text { men from medical } \\
\text { exam for compulsory military } \\
\text { service. } \\
\text { Study } 1^{14} \text { used hospital admission } \\
\text { records as outcome. Study } 2^{15} \\
\text { used sub-sample of subjects ( } \mathrm{n}= \\
28 \text { runners, } 31 \text { soccer, } 19 \text { weight } \\
\text { lifters and } 29 \text { shooters). Shooters } \\
\text { (i.e. no impact or elevated joint } \\
\text { pressure) were controls. Study } \\
3^{13} \text { used self-reported pain and } \\
\text { used follow-up of } 30-75 \text { yrs. }\end{array}$ \\
\hline
\end{tabular}

Three different studies, all historical cohort with 20-65 yr follow-up.

Independent variables by recall.

Blinded assessment of $x$ rays in Study 1 (Nationa

Registry) and Study 2.

Registry) and Study 2 .
Outcome in study 3 was Outcome in
self-report. (1)

tudy 1: Survival analysis graph: Risk of hospital admission for OA (hip, knee or ankle) similar among controls and distance running/skiing until age 70 , then controls less admissions. All other sports had higher admission rates throughout life.

OR (adjusted for age, occupation and BMI):

\begin{tabular}{|l|c|}
\hline Sport & OR \\
\hline Distance running/cross-country skiing & $2.4(1.3$ to 4.7$)$ \\
\hline
\end{tabular}

Study 2: Used shooters as control group. Stepwise regression final model: BMI, previous injury, hours in team/endurance/power sport, hours in heavy or kneeling/squat work.

\begin{tabular}{|l|c|c|}
\hline & OR & OR (final model) \\
\hline Runners & $\begin{array}{c}4.8(0.48 \text { to } 47) \\
\text { age adjusted }\end{array}$ & $\begin{array}{c}\text { "Not } \\
\text { significant" }\end{array}$ \\
\hline $\begin{array}{l}\text { Previous } \\
\text { injury }\end{array}$ & $\begin{array}{c}7.9 \text { (univariate, from } \\
\% \text { data supplied) }\end{array}$ & $6.0(1.3$ to 27.8$)$ \\
\hline
\end{tabular}

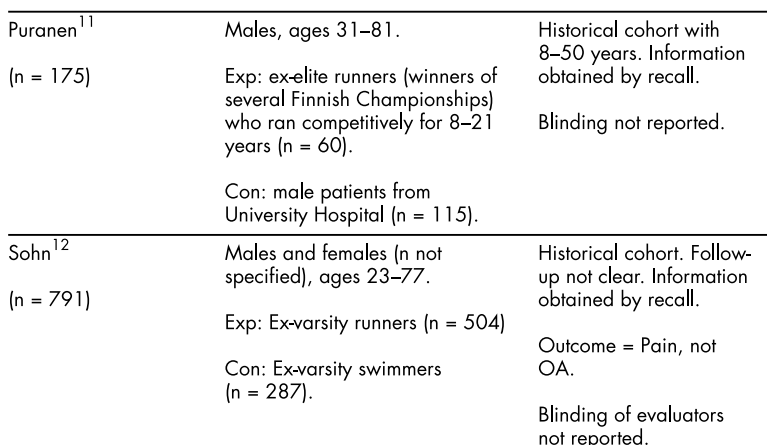

\begin{tabular}{|l|c|c|}
\hline & Mild-Mod OA & Severe OA \\
\hline Runners & $2.7 \%$ & $1.4 \%$ \\
\hline Control & $7.0 \%$ & $1.7 \%$ \\
\hline
\end{tabular}

Although $9 \%$ of runners and $15 \%$ of controls had osteophytes, no subjects with only osteophytes complained of pain.

Main Outcome = Pain

\begin{tabular}{|l|c|c|}
\hline & $\begin{array}{c}\text { Severe hip or } \\
\text { knee pain }\end{array}$ & $\begin{array}{c}\text { Any hip or } \\
\text { knee pain }\end{array}$ \\
\hline Runners & $2 \%$ & $15 \%$ \\
\hline Swimmers & $2.4 \%$ & $19 \%$ \\
\hline
\end{tabular}

Proportion of group with surgery for pain: runners $=0.8 \%$ swimmers $=2.1 \%$.

Average Mileage Among Runners Split by Age

\begin{tabular}{|l|c|c|}
\hline Age & Pain & No pain \\
\hline $0-40$ & 58.5 & 54 \\
\hline $40-49$ & 33.4 & 27.9 \\
\hline $50-59$ & 30 & 24.9 \\
\hline $60-69$ & 17.9 & 16.3 \\
\hline $70+$ & 18.8 & 18.8 \\
\hline
\end{tabular}

Response rate not reported.

OA not defined but reported numbers mean that a diagnosis required more than just osteophytes.

X-rays done between 1963 and 1974 , but questionnaire on pain only in 1974. Follow-up time is therefore not clear.

Response rate $=504 / 658(77 \%)$ for runners and $287 / 495$ (58\%) for swimmers.

This study used pain rather than $O A$ as the outcome.

Exp subjects had competed between 1930-1960, and the age of subjects ranged 23-77. This means that survey had to be done 1985

Ex-runners with pain had slightly increased mileage compared with those who did not have pain, but the differences appear clinically have pain, but the differences appear clinically
irrelevant and were not statistically significant.

Age not different between groups, but not formally analysed.

\section{Running/soccer}

Overall, the three cross sectional running studies concluded that exercise is not associated with $\mathrm{OA}_{,}^{4-6}$ and the three casecontrol running studies found mixed results but overall suggested that some higher intensity activities may be associated with the development of OA. ${ }^{7-9}$

With respect to historical cohort studies on running, there was no increased risk of $\mathrm{OA}$ in runners in four of seven historical cohort studies. This was true for (a) 27 elite Danish male orienteering runners compared with hospital controls, ${ }^{10}$ (b) 60 Finnish male elite runners compared with hospital controls, ${ }^{11}$ (c) 504 US college varsity cross country runners compared with varsity swimmers, ${ }^{12}$ and $(d) 1282$ Finnish exelite male endurance athletes after controlling for previous injury (three papers published on the same cohort ${ }^{13-15}$ ).

In one study showing a possible increased risk of OA in runners, ${ }^{16}$ running pace was a better predictor than running mileage even though the wear and tear hypothesis would predict that OA should increase with each vertical impactthat is, step-more so than horizontal speed. Horizontal speed would be important if the running technique was suboptimal, and the runner placed the foot in front of the body at heel strike, thereby creating a large breaking force. However, this breaking force slows the runner down and 
Table 1 Contd

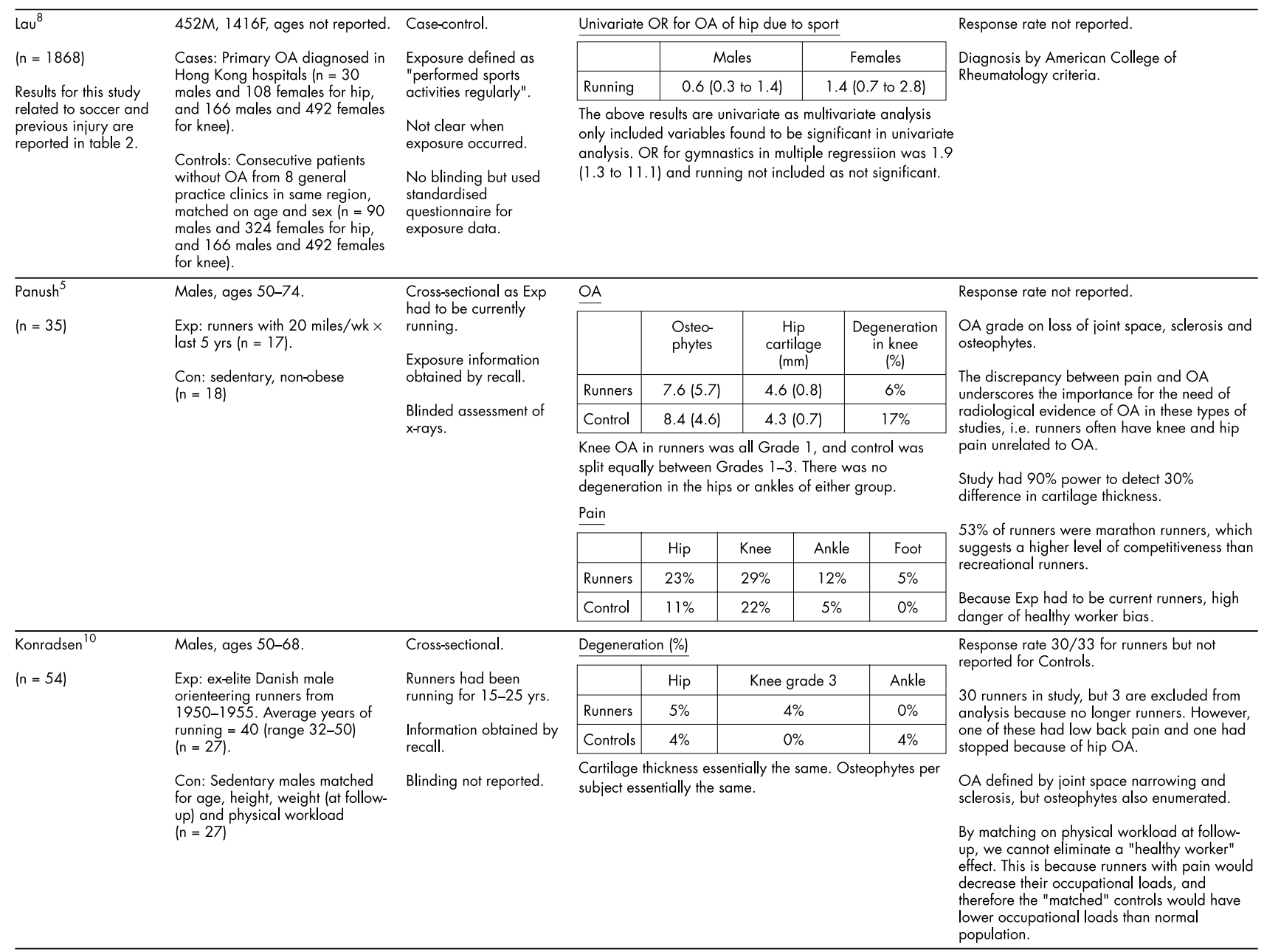

Studies are sorted by whether the results suggest an association between exercise and OA or not, and by study design within each category.

- OA: osteoarthritis

- Exp: Exercise group

- Con: Control group

- Historical cohort: For the purpose of this review, any observational study for which the exposure clearly predates the outcome was considered either a cohort study (groups assembled based on exposure history) or a case-control study (groups assembled based on presence or absence of OA). Although some historical cohort studies might be considered cross-sectional studies by other authors (e.g. when all information obtained by interview at one point in time), we felt that the important distinction between these two categories is the ability to determine if the exposure preceded the outcome (i.e. historical cohort study).

therefore would not be expected to correlate with running speed.

Another historical cohort study suggested an increased risk in runners younger than 50 who run $>20$ miles a week. ${ }^{17}$ An effect of mileage was not seen in subjects older than 50, which again is contrary to what would be predicted by the wear and tear hypothesis. In the remaining study showing a possible increase in $\mathrm{OA}^{18}{ }^{18}$ osteophytes were associated with elite exercise, but the OR for joint space narrowing was close to 1 for the knee $(1.2,95 \%$ CI 0.7 to 1.9$)$ and for the hip (1.6, $95 \%$ CI 0.7 to 3.5$)$. Within the control population, moderate exercise was not associated with joint space narrowing of the hip or knee, although there was a trend toward decreased joint space of the hip in the higher participation category (1.8, $95 \%$ CI 0.73 to 3.48 ).

In the only prospective study, Lane and colleagues ${ }^{19-21}$ found no difference in the development or progression of
OA between 41 runners and matched controls after two, five, or nine years. In another study that simply categorised exposure as "sport participation", there was again a lack of progression of OA. ${ }^{22}$

Besides pure running, team sports such as soccer have also been implicated as a cause of OA. Although Klunder $e t$ al $^{23}$ found a higher proportion of radiographic hip OA in soccer players, 13/30 patients with OA had previous injuries compared with only 3/19 controls. Lindberg et $a^{24}$ found hip OA was higher only in the elite soccer players ( $14.1 \%$ for elite, $4.2 \%$ for non-elite, and $4.2 \%$ for control).

In summary, these findings suggest that moderate intensity impact sports do not cause or worsen OA. OA in high intensity or elite sports could be due to a threshold effect-that is, wear and tear only occurs after a threshold-or some other factor, and a closer examination is warranted. 
Table 2 Details of studies related to soccer exposure $(95 \% \mathrm{Cl}$ in parentheses)

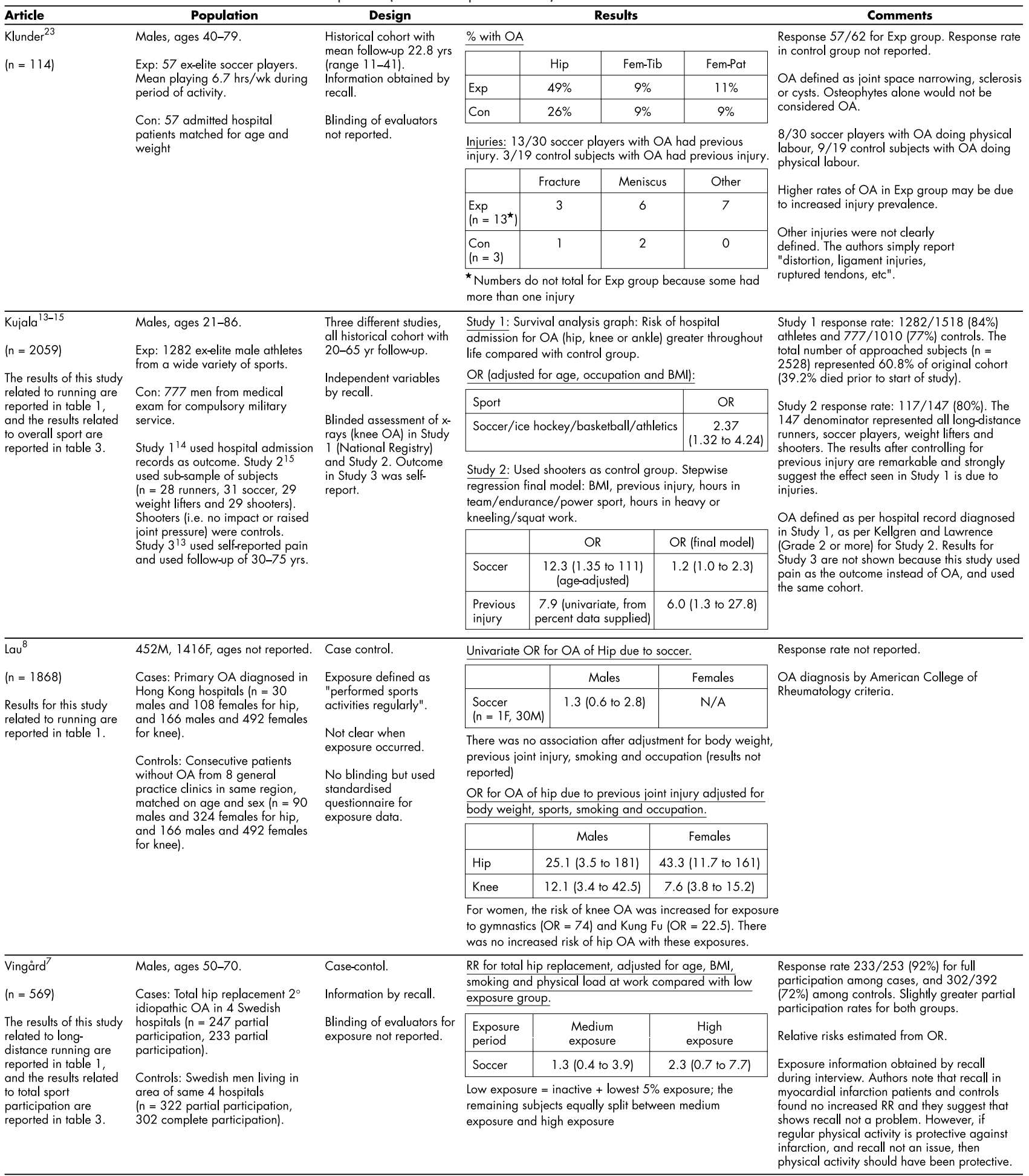

\section{Elite sports}

Kulula's group ${ }^{13-15}$ found that the risk of hip or knee disability was only increased in elite team sports (previous injury not controlled for $^{13}$ ). When the same cohort of athletes was compared with 1403 controls without controlling for previous injury, ${ }^{14}$ OA was increased in all types of athletes (OR range 1.73-2.17), but the greatest increase occurred in wrestling (OR 2.73, 95\%CI 1.63 to 4.64 ), weight lifting (OR 2.74, 95\%CI 1.27 to 5.9 ), soccer (OR 2.1,95\%CI 1.2 to 3.8 ), and ice hockey
(OR 4.2, 95\%CI 2.2 to8.0). Three of four of these exposures do not involve impact, suggesting that wear and tear is not a likely cause. In a subsequent study of a subgroup of the same population but now controlling for previous injury, ${ }^{15}$ the risk was now considerably less (OR 1.2, 95\%CI 1.0 to 2.3) and much less than the risk associated with previous injury (OR $6.0,95 \%$ CI 1.3 to 27.8 ). The presence of previous injury may also partially explain the higher rate of OA in the previously mentioned Lindberg study. ${ }^{24}$ Using the same population, the 
Table 2 Contd

\begin{tabular}{|c|c|c|c|c|c|c|c|c|}
\hline \multirow{6}{*}{$\begin{array}{l}\text { Lindberg }^{24} \\
\text { ( } \mathrm{n}=858 \text { ) }\end{array}$} & \multirow{6}{*}{$\begin{array}{l}\text { Males, ages } 40-88 \text {. } \\
\text { Exp: ex-soccer players, with } \\
71 / 286 \text { being elite. } \\
\text { Con: } 572 \text { males from same city } \\
\text { population records, matched for } \\
\text { age (soccer history unknown). }\end{array}$} & \multirow{6}{*}{$\begin{array}{l}\text { Cross-sectional study but } \\
\text { exposure likely preceded } \\
\text { outcome by } 15-63 \text { yrs. } \\
\text { Information obtained } \\
\text { from hip x-rays over } \\
38 \text { yrs. } \\
\text { Blinding of evaluators } \\
\text { not reported. }\end{array}$} & \multicolumn{5}{|l|}{$\%$ Hip OA } & \multirow{6}{*}{$\begin{array}{l}\text { Response rate not given. } \\
\text { OA definition restricted so that joint space } \\
\text { narrowing had to be present. } \\
\text { History of soccer playing in control group is } \\
\text { unknown, but control subjects did not play } \\
\text { competitively for the teams included in the } \\
\text { experimental group. } \\
\text { Although timing between outcome and } \\
\text { exposure not precisely reported, average age } \\
\text { at diagnosis in Exp group was } 47 \text { yrs, and all } \\
\text { Exp group subjects played competitive soccer } \\
\text { until at least } 25 \text { years old. }\end{array}$} \\
\hline & & & & \multicolumn{2}{|c|}{$\begin{array}{l}\text { Older group } \\
(64-88)\end{array}$} & \multicolumn{2}{|c|}{$\begin{array}{l}\text { Younger group } \\
\quad(40-64)\end{array}$} & \\
\hline & & & Elite & \multicolumn{2}{|c|}{$14.7 \%$} & \multicolumn{2}{|c|}{$13.5 \%$} & \\
\hline & & & Non-elite & \multicolumn{2}{|c|}{$3.1 \%$} & \multicolumn{2}{|c|}{$2.7 \%$} & \\
\hline & & & Control & \multicolumn{2}{|c|}{$6.1 \%$} & \multicolumn{2}{|c|}{$1.8 \%$} & \\
\hline & & & & & & & & \\
\hline \multirow{6}{*}{$\begin{array}{l}\text { Solonen }^{6} \\
(n=76)\end{array}$} & \multirow{3}{*}{$\begin{array}{l}\text { Males, ages } 18-37 \text { for Exp and } \\
18-88 \text { for control. } \\
\text { Exp: } 36 \text { active soccer players } \\
\text { with } 5-23 \text { yrs experience (many } \\
\text { national athletes). }\end{array}$} & \multirow{2}{*}{$\begin{array}{l}\text { Cross-sectional as all } \\
\text { Exp group still active } \\
\text { soccer players. }\end{array}$} & \multicolumn{5}{|c|}{ Hip: No OA in either group. } & \multirow{6}{*}{$\begin{array}{l}\text { Response rate } 36 / 60 \text {. As they were currently } \\
\text { active and the reason for refusal was not } \\
\text { provided, the subjects who refused may have } \\
\text { been trying to hide their injuries. } \\
\text { No precise definition for OA. } \\
\text { No OA of hip or tibio-femoral component of } \\
\text { the knee in either group. This is highly unusual }\end{array}$} \\
\hline & & & \multicolumn{5}{|c|}{$\begin{array}{l}\text { Knee: } 28 \% \text { of soccer players mild-moderate OA of Pat-fem } \\
\text { joint. }\end{array}$} & \\
\hline & & \multirow{2}{*}{$\begin{array}{l}\text { Information obtained by } \\
\text { recall. }\end{array}$} & & Hip & Fem-Tib & Fem-Pat & Talo-crural & \\
\hline & \multirow{3}{*}{$\begin{array}{l}\text { Con: } 40 \text { subjects with acute lower } \\
\text { extremity injury and no known } \\
\text { history of soccer. }\end{array}$} & & Exp & $0 \%$ & $0 \%$ & $28 \%$ & $92 \%$ & \\
\hline & & \multirow{2}{*}{$\begin{array}{l}\text { Blinding of evaluators } \\
\text { not reported. }\end{array}$} & Con & $0 \%$ & $0 \%$ & $21 \%$ & $20 \%$ & \\
\hline & & & \multicolumn{5}{|c|}{$\begin{array}{l}73 \% \text { of soccer players had moderate-severe knee injuries, } \\
\text { and } 80 \% \text { had severe ankle injuries. }\end{array}$} & \\
\hline
\end{tabular}

All studies suggested soccer players were at risk of OA, but where studied, only in elite sports or those without injury. Studies are sorted by design.

- OA: osteoarthritis

- Exp: Exercise group

- Con: Control group

- Historical cohort: For the purpose of this review, any observational study for which the exposure clearly predates the outcome was considered either a cohort study (groups assembled based on exposure history) or a case-control study (groups assembled based on presence or absence of OA). Although some historical cohort studies might be considered cross-sectional studies by other authors (e.g. when all information obtained by interview at one point in time), we felt that the important distinction between these two categories is the ability to determine if the exposure preceded the outcome (i.e. historical cohort study).

subsequent publication ${ }^{25}$ noted that $33 \%$ of elite soccer players with previous meniscectomy or ACL tear developed knee OA compared with $11 \%$ in those without these injuries. The same may also be true for hip OA, but this type of analysis has yet to be published.

\section{DISCUSSION}

The results of this literature review strongly suggest that regular mild-moderate impact exercise does not increase the risk of $\mathrm{OA}$, and that there is some evidence that it does not increase symptoms in patients with mild-moderate OA. This evidence supports the muscle dysfunction hypothesis as a cause of OA over the wear and tear hypothesis.

\section{Running/soccer}

The wear and tear hypothesis predicts that any type of impact such as running would increase OA, or worsen it once developed. However, the clinical evidence suggests that recreational running and soccer do not increase the risk of OA. In the basic science literature, canine cartilage adapts favourably to moderate running, ${ }^{26}$ and running did not worsen immobilisation induced OA in rabbit knees, ${ }^{27}$ which is consistent with the prospective study reported by Lane et al. ${ }^{21}$ In addition, the finding that degeneration occurs with forced exhaustive running in $\operatorname{dogs}^{28} 29$ is also consistent with the muscle dysfunction hypothesis because exhaustion will prevent the muscles from absorbing force. Although some might believe that marathon running could be analogous to forced exhaustive exercise in dogs, most marathon training is done at much lower mileage. Although subjects may be tired, they are not exhausted. The actual marathon is run only a few times a year, whereas the dogs were run to exhaustion regularly.
Most of the subjects in the clinical studies in this review had intact menisci, and presumably no major malalignment. In subjects with previous meniscectomy, Roos et al $^{30}$ reported no effect of exercise on the incidence of OA. This contradicts the basic science finding that running increased the risk of $\mathrm{OA}$ in meniscectomised sheep. ${ }^{31}$ Although there were no studies on the effect of exercise in subjects with malalignment, Sharma et $a^{32}$ reported that disease progression occurs more rapidly in this population. How does the muscle dysfunction hypothesis relate to these populations? The wear and tear hypothesis predicts that cartilage damage precedes bone sclerosis. However, the reverse occurred in adult rabbit knees subjected to one hour impulse loading a day. ${ }^{33}$ The sclerosis was associated with numerous healing trabecular fractures, suggesting that the principle force absorber in anaesthetised animals is not cartilage but bone. This is supported by in vitro findings suggesting that articular cartilage does not absorb force, ${ }^{34}$ but does redistribute force. $^{35-37}$ If enough microtrabecular damage occurs over a short period of time, sclerosis would occur as an adaptationthat is, damage would be less likely in sclerotic bone. ${ }^{38}$ Within this paradigm, malalignment and meniscectomy could increase the risk of $\mathrm{OA}^{30} 32$ because they prevent the normal redistribution of force-that is, even in normal knees, the muscles do not absorb $100 \%$ of the force-which makes micro-damage more likely to occur. Finally, the sclerotic changes in underlying bone stiffness may increase the stress on articular cartilage, ${ }^{39}$ which would lead to increased degenerative changes in both meniscal and articular cartilage.

\section{Elite sports}

Although the findings suggest that recreational sports are innocuous with respect to developing OA, they do suggest that participation in elite sports increases the risk of OA. This 
Table 3 Details of studies related to "other" exposure $(95 \% \mathrm{Cl}$ in parentheses)

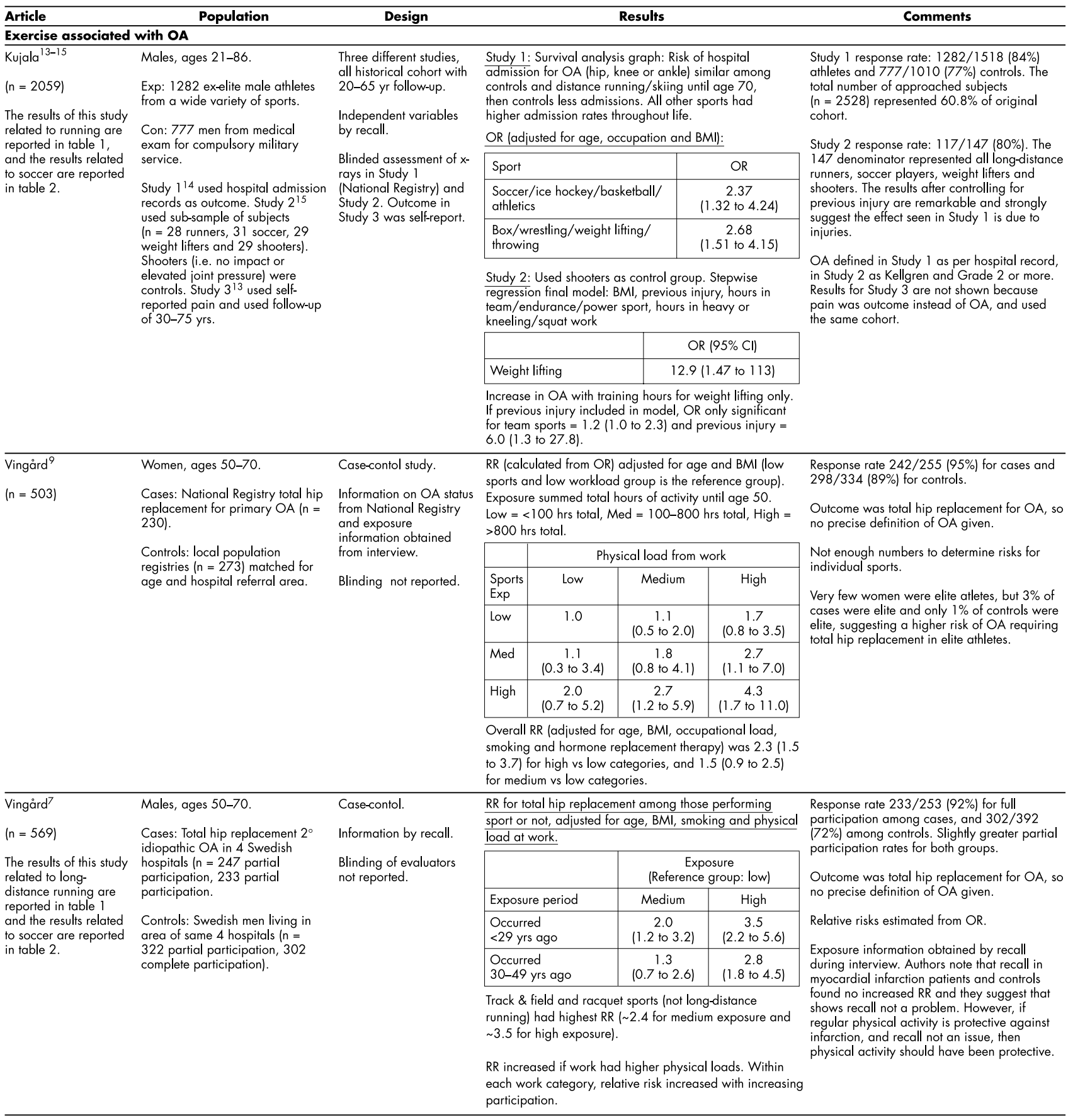

occurred in impact sports, such as soccer, and also in nonimpact sports, such as weightlifting and hockey. Unlike the wear and tear hypothesis, the muscle dysfunction hypothesis predicts these results through the increased risk of injury that occurs with elite sports and the subsequent muscle dysfunction that occurs with injury. In support of these findings, others have found that young adults with previous knee injury are more likely to develop $\mathrm{OA}^{, 22}{ }^{40}$ and that previous hip injury increases the risk of hip OA. ${ }^{40}$

There are three possible mechanisms by which previous injury could increase the risk of OA. Firstly, the damage may occur at the time of the injury and OA develops over the subsequent years. Secondly, the associated ligamentous instability with major injury leads to recurrent articular cartilage damage. Finally, the associated muscle dysfunction with injury leads to recurrent articular cartilage damage because the impact forces are no longer being absorbed appropriately.

If damage occurred at the time of injury, and the wear and tear hypothesis is correct, then articular cartilage damage should overlie areas of bone damage. However, there was no correlation between the location of a femoral bone bruise and articular or meniscal cartilage damage observed at surgery for ACL reconstruction. ${ }^{41}$ The possibility of "sub-clinical articular damage" remains theoretical at the present time. Finally, Felson et $a l^{42}$ recently found a strong correlation between location of bone marrow oedema on magnetic resonance images and progression of OA. If bone marrow oedema is indeed a strong predictor of progression, it suggests that bone injury is an early sign of damage. Future research should 
Table 3 Contd

\begin{tabular}{|c|c|c|c|c|c|c|c|c|}
\hline \multirow{6}{*}{$\begin{array}{l}\operatorname{Roos}^{25} \\
(n=858)\end{array}$} & \multirow{6}{*}{$\begin{array}{l}\text { Males, ages } 40-88 \text {. } \\
\text { Exp 1: } 71 \text { ex-elite male soccer } \\
\text { players. } \\
\text { Exp2: } 215 \text { non-elite male soccer } \\
\text { players. } \\
\text { Con: Two age-matched male } \\
\text { controls per Exp from population } \\
\text { database. }\end{array}$} & \multirow{6}{*}{$\begin{array}{l}\text { Historical cohort with } \\
15-63 \text { yr follow-up. } \\
\text { Historical information } \\
\text { obtained by interview } \\
\text { and current status by } \\
\text { interview and exam. } \\
\text { Blinded assessment of } \\
\text { x-rays. }\end{array}$} & \multicolumn{5}{|c|}{ Prevalence of $O A$ in groups. } & \multirow{6}{*}{$\begin{array}{l}\text { Response rate not reported. } \\
\text { There was no standard follow-up and not all } \\
\text { subjects had x-rays. Rather, } x \text {-ray records were } \\
\text { pulled from radiology sources (only } 253 / 858 \\
\text { had x-rays). } \\
\text { OA defined by joint space narrowing }>50 \% \text { of } \\
\text { other knee compartment or contralateral knee, } \\
\text { or joint space less than } 3 \mathrm{~mm} \text {. } \\
\text { The lower prevalence of OA in non-elite } \\
\text { compared with elite suggests higher rates of } \\
\text { OA in soccer mostly only in elite players. The } \\
\text { difference in injury rates may be the } \\
\text { mechanism (only ACL and menisectomy } \\
\text { recorded). }\end{array}$} \\
\hline & & & \multirow{2}{*}{\begin{tabular}{|l|} 
Category \\
Elite \\
\end{tabular}} & \multirow{2}{*}{\multicolumn{2}{|c|}{$\begin{array}{c}\begin{array}{c}\% \text { OA } \\
\text { total group }\end{array} \\
15.5 \% \\
\end{array}$}} & \multirow{2}{*}{$\begin{array}{c}\% \text { of } \\
\text { Uninjured }\end{array}$} & \multirow{2}{*}{$\begin{array}{c}\% \text { Major } \\
\text { surgery } \\
9 \%\end{array}$} & \\
\hline & & & & & & & & \\
\hline & & & Non-elite & \multicolumn{2}{|c|}{$4.2 \%$} & $3 \%$ & $2 \%$ & \\
\hline & & & Control & $1.6 \%$ & & $0 \%$ & $0 \%$ & \\
\hline & & & \multicolumn{5}{|c|}{$\begin{array}{l}14 \% \text { of soccer players (not separated by elite status) had } \\
\text { menisectomies compared to } 2 \% \text { in control group. } \mathrm{ACL} \\
\text { injuries occurred in } 4.2 \% \text { of elites, } 1.8 \% \text { of non-elites and } \\
0 \% \text { of controls. }\end{array}$} & \\
\hline $\begin{array}{l}\operatorname{Roos}^{30} \\
(n=175)\end{array}$ & $\begin{array}{l}130 \text { males and } 45 \text { females ages } \\
35-78 . \\
\text { Exp. Total menisectomy in } 1973 \\
(n=107) \text { without OA at the time } \\
\text { of surgery. }\end{array}$ & $\begin{array}{l}\text { Historical cohort with } \\
21 \text {-yr follow-up. } \\
\text { Historical information } \\
\text { obtained by recall and } \\
\text { current status by } \\
\text { interview and exam. }\end{array}$ & \multirow{2}{*}{\multicolumn{5}{|c|}{$\begin{array}{l}\text { Results for activity not shown. Article does say "neither } \\
\text { occupation nor sports activity were significant risk } \\
\text { factors for OA in this study." }\end{array}$}} & $\begin{array}{l}\text { Response rate } 107 / 123 \text { in Exp group. For } \\
\text { control group, } 214 \text { originally designated but } \\
16 \text { excluded. Of remaining } 198,83 \text { refused } \\
\text { initially (leaving } 115 \text { ). Of those remaining, } 40 \\
\text { excluded as double-controls, six refused to } \\
\text { continue and } 1 \text { was excluded. }\end{array}$ \\
\hline & $\begin{array}{l}\text { Con. From the National } \\
\text { Population Registry }(n=68)\end{array}$ & $\begin{array}{l}\text { Blinded assessment of } \\
\text { x-rays. }\end{array}$ & & & & & & $\begin{array}{l}\text { OA required joint space narrowing. } \\
\text { Power analysis suggested only needed } 60 \\
\text { controls. }\end{array}$ \\
\hline \multirow[t]{9}{*}{$\begin{array}{l}\text { Cooper }^{22} \\
(n=354)\end{array}$} & \multirow[t]{2}{*}{$\begin{array}{l}\text { Males }(n=99) \text { and females }(255) \\
\text { with mean age } 75.8 \text { yrs (IQR }= \\
69.5-80.9) .\end{array}$} & $\begin{array}{l}\text { Historical cohort with } \\
5 \text { yr follow-up. }\end{array}$ & \multicolumn{5}{|c|}{$\begin{array}{l}\text { OR for OA (adjusted for age, sex, BMl, knee pain at } \\
\text { baseline and Heberden's nodes). }\end{array}$} & $\begin{array}{l}\text { Response rate }=354 / 583(61 \%) \text { of original } \\
\text { cohort were available at follow-up. }\end{array}$ \\
\hline & & \multirow{4}{*}{$\begin{array}{l}\text { Exposure information } \\
\text { obtained by interview } \\
\text { and outcome by } x \text {-ray. } \\
\text { Blinded assessment of } \\
\text { x-rays. }\end{array}$} & & & & ade IOA & Grade II OA & \multirow{8}{*}{$\begin{array}{l}\text { The increased risk of osteophytes with sport } \\
\text { participation is consistent with other studies, as } \\
\text { is the absence of the development or } \\
\text { progression of joint space narrowing. } \\
\text { The increased risk for incident Grade I or II } \\
\text { OA with previous injury is consistent with } \\
\text { previous studies. The lack of an increased risk } \\
\text { for progression of OA with previous injury is } \\
\text { new information and appropriate on face } \\
\text { value. The injury may cause the OA, but once } \\
\text { the damage is there, the mechanisms for } \\
\text { progression would be based on the damage } \\
\text { and not the original cause. }\end{array}$} \\
\hline & \multirow{7}{*}{$\begin{array}{l}\text { Exp: weekly participation in } \\
\text { sports for at least } 10 \text { yrs after } \\
\text { leaving school. } \\
\text { Con: Subjects who did not fit Exp } \\
\text { definition. }\end{array}$} & & \multicolumn{5}{|l|}{ Incidence } & \\
\hline & & & \multirow{2}{*}{\multicolumn{2}{|c|}{\begin{tabular}{|l|} 
Sports participation \\
Previous injury \\
\end{tabular}}} & \multicolumn{2}{|c|}{$3.2(1.1$ to 9.1$)$} & $1.0(0.5$ to 2.1$)$ & \\
\hline & & & & & 4.8 & .0 to 24.1$)$ & $2.5(0.8$ to 8.1$)$ & \\
\hline & & \multirow{4}{*}{$\begin{array}{l}\text { Grade I OA was } \\
\text { presence of osteophytes. } \\
\text { Grade II OA was } \\
\text { presence of joint space } \\
\text { narrowing. }\end{array}$} & \multicolumn{5}{|c|}{ Progression } & \\
\hline & & & \multirow{2}{*}{\multicolumn{2}{|c|}{\begin{tabular}{l|} 
Sports participation \\
Previous injury
\end{tabular}}} & \multicolumn{2}{|c|}{$0.7(0.4$ to 1.6$)$} & $0.9(0.3$ to 2.5$)$ & \\
\hline & & & & & 1.2 & 0.5 to 3.0$)$ & $1.1(0.3$ to 4.4$)$ & \\
\hline & & & & & & & & \\
\hline
\end{tabular}

Studies are sorted by whether the results suggest an association between exercise and $\mathrm{OA}$, and by study design within each category.

- OA: osteoarthritis

- Exp: Exercise group

- ACL: anterior cruciate ligament

- Con: Control group

- Historical cohort: For the purpose of this review, any observational study for which the exposure clearly predates the outcome was considered either a cohort study (groups assembled based on exposure history) or a case-control study (groups assembled based on presence or absence of OA). Although some historical cohort studies might be considered cross-sectional studies by other authors (e.g. when all information obtained by interview at one point in time), we felt that the important distinction between these two categories is the ability to determine if the exposure preceded the outcome (i.e. historical cohort study).

examine the subgroup of patients who had osteophytes without joint space narrowing at baseline to see if bone marrow oedema preceded the articular cartilage damage.

If ligamentous instability of the joint after an ACL tear causes OA, then ACL reconstruction should minimise the risk of OA. However, clinical studies (albeit with their limitations) suggest that it may not. ${ }^{43}{ }^{44}$ Other authors have suggested that it is the underlying bone injury that occurs at the time of ACL rupture that is the cause of OA. Yet, OA is produced in dogs and cats by isolated transection of the ACL without associated bone damage at the time of injury. ${ }^{36} 45$ In the muscle dysfunction hypothesis, the loss of proprioception information from the ACL would result in increased force transmission to the bone, and increased OA. Further, evidence from biomechanical studies reveal an increase in loading of the non-transected knee, which does not develop $\mathrm{OA}^{47}$ which again suggests that normal muscles can absorb the regular amounts of stress and strain across a joint and that "wear and tear" is not the cause of OA in uninjured limbs.
The muscle dysfunction hypothesis is based on the finding that muscle fatigue increases the impact forces crossing a joint, ${ }^{48}$ which suggests that properly contracting muscles are the main absorber of force. Whether the muscle cannot contract properly because of age or fatigue or disuse atrophy, or because of injury induced weakness (strains) or loss of proprioception (ACL tears), the effect is the same; more force is transmitted to the bone, which leads to increased microtrabecular damage, which leads to sclerosis, which could lead to changes in the stresses and strains across the articular cartilage, and then joint space narrowing. The added stress would then lead to the characteristic changes observed in periarticular tissue. Note that this hypothesis would predict an increased risk of OA with less severe injuries than are usually accounted for in studies-for example, quadriceps contusion could lead to increased risk of OA even though there was no ligamentous damage-and also the greater risk of hip OA compared with knee OA in soccer players ${ }^{23}$ - that is, groin strains occur often in soccer but rarely with running. In addition, it would predict a higher rate of hip OA in 
subjects with knee injuries, and vice versa because the muscles of the thigh would be expected to absorb force across both joints. However, this analysis has not yet been published.

\section{Other activity and obesity}

The objective of this article was to assess the risk of OA with exercise. Although a detailed discussion of the risk of OA with exposure to various occupations is beyond its scope, the muscle dysfunction hypothesis can explain findings in this area as well. Briefly, if a person is forced to work when fatigued or injured-for example, a farmer-the muscles no longer absorb the forces crossing a joint and there would be an expected increase in microtrabecular damage, then sclerosis, and then OA. For example, in the study by Lau et $a l_{,}^{8}$ for those subjects with occupational exposures that required climbing 15 flights of stairs or more, the OR for developing OA was 5.1 (95\%CI 2.5 to 10.2$)$ for women and 2.5 (95\%CI 1.0 to 6.4 ) for men in the entire study, but 34.0 (95\%CI 4.7 to 248.4 ) overall for those with previous injury. Similarly, the OR for developing OA in those subjects with occupational exposures that required lifting $\geqslant 10 \mathrm{~kg}$ more than 10 times a week was $2.0(95 \%$ CI 1.2 to 3.1$)$ for the entire group and 25.9 (95\%CI 8.1 to 82.4 ) for those with previous injury.

Finally, obesity is a well recognised risk factor for OA. ${ }^{250}$ The muscle dysfunction hypothesis explains this relation as well. The added weight means that muscles must absorb even more force and therefore must be stronger and have greater endurance or there will be a "relative dysfunction". However, obesity is associated with physical inactivity and therefore relative muscle dysfunction. With respect to mortality, most of the evidence suggests that obesity is not related to mortality if there is adjustment for physical fitness. ${ }^{51}$ Future studies should explore whether the relation between obesity and $\mathrm{OA}$ is similar to that between obesity and mortality.

\section{CONCLUSIONS}

The muscle dysfunction hypothesis that was originally proposed based on basic science evidence is supported by the clinical literature as well. This includes:

- Strengthening and endurance exercise relieves symptoms in patients with mild and moderate $\mathrm{OA}^{, 52-54}$ and poor knee proprioception is associated with increased disability in patients with OA. ${ }^{55}$

- Regular running increases joint space width whereas forced exhaustive running-that is, fatigue-decreases joint space width. ${ }^{28} 29$

- Major injuries are associated with a high rate of OA.

- Because muscles provide the "dynamic" joint stability during movement, some signs of OA-that is, osteophytes and capsular thickening-may be an attempt by the body to increase joint stability in the presence of muscle dysfunction induced dynamic instability.

- A wide variety of elite sports, but not recreational exercise, are associated with OA. This effect is greatly reduced when major injuries are controlled for. Because elite athletes often play while injured-that is, on weak muscles- the muscle dysfunction hypothesis predicts that there would still be an increase in risk if minor injuries are not controlled for-for example, groin strain in soccer and hip OA.

The most important implication of the muscle dysfunction hypothesis is that proper rehabilitation after an injury may be important in the prevention of OA. A study designed to definitively test the role of muscle dysfunction would require detailed prospectively collected data, controlling for proper rehabilitation after major and minor injuries using appropriate strength testing and close supervision. That being said, the hypothesis that best explains the evidential relation between exercise and OA currently available today is the muscle dysfunction hypothesis.

\section{ACKNOWLEDGEMENTS}

Funding by the Chercheur-Boursier Clinicien program of the Fonds de Recherche en Santé du Québec is gratefully acknowledged.

\section{REFERENCES}

1 Badley EM. The effect of osteoarthritis on disability and health care use in Canada. J Rheumatol Suppl 1995;43:19-22.

2 Felson DT, Lawrence RC, Dieppe PA, et al. Osteoarthritis: new insights. Part 1. The disease and its risk factors. Ann Intern Med 2000;133:635-46.

3 Hurley MV. The role of muscle weakness in the pathogenesis of osteoarthritis. Rheum Dis Clin North Am 1999;25:283-98.

4 Lane NE, Bloch DA, Jones $\mathrm{HH}$, et al. Long-distance running, bone density, and osteoarthritis. JAMA 1986;255:1147-51.

5 Panush RS, Schmidt C, Caldwell JR, et al. Is running associated with degenerative joint disease? JAMA 1986;255:1152-4.

6 Solonen KA. The joints of the lower extremities of football players. Ann Chir Gynecol Fen 1966;55:176-80.

7 Vingard E, Alfredsson L, Goldie I, et al. Sports and osteoarthrosis of the hip. Am J Sports Med 1993;21:195-200.

8 Lau EC, Cooper C, Lam D, et al. Factors associated with osteoarthritis of the hip and knee in Hong Kong Chinese: obesity, joint injury, and occupational activities. Am J Epidemiol 2000;152:855-62.

9 Vingard E, Alfredsson L, Malchau H. Osteoarthrosis of the hip in women and its relationship to physical load from sports activities. Am J Sports Med 1998;26:78-82.

10 Konradsen L, Hansen EB, Sondergaard L. Long distance running and osteoarthrosis. Am J Sports Med 1990;18:379-81.

11 Puranen J, Ala-Ketola L, Peltokallio P, et al. Running and primary osteoarthritis of the hip. BMJ 1975;2:424-5.

12 Sohn RS, Micheli $\amalg$. The effect of running on the pathogenesis of osteoarthritis of the hips and knees. Clin Orthop 1985;198:106-9.

13 Kettunen JA, Kujala UM, Kaprio J, et al. Lower-limb function among former elite male athletes. Am J Sports Med 2001 ;29:2-8.

14 Kujala UM, Kaprio J, Sarna S. Osteoarthritis of weight bearing joints of lower limbs in former elite male athletes. BMJ 1994;308:231-4.

15 Kujala UM, Kettunen J, Paananen H, et al. Knee osteoarthritis in former runners, soccer players, weight lifters, and shooters. Arthritis Rheum 1995; 38:539-46.

16 Marti B, Knobloch M, Tschopp A, et al. Is excessive running predictive of degenerative hip disease? Controlled study of former elite athletes. BMJ 1989;299:91-3.

17 Cheng Y, Macera CA, Davis DR, et al. Physical activity and self-reported, physician-diagnosed osteoarthritis: is physical activity a risk factor? J Clin Epidemiol 2000;53:315-22.

18 Spector TD, Harris PA, Hart DJ, et al. Risk of osteoarthritis associated with long-term weight-bearing sports: a radiologic survey of the hips and knees in female ex-athletes and population controls. Arthritis Rheum 1996;39:988-95.

19 Lane NE, Bloch DA, Hubert HB, et al. Running, osteoarthritis, and bone density: initial 2-year longitudinal study. Am J Med 1990;88:452-9.

20 Lane NE, Michel B, Bjorkengren A, et al. The risk of osteoarthritis with running and aging: a 5-year longitudinal study. J Rheumatol 1993;20:461-8.

21 Lane NE, Oehlert JW, Bloch DA, et al. The relationship of running to osteoarthritis of the knee and hip and bone mineral density of the lumbar spine: a 9 year longitudinal study. J Rheumatol 1998;25:334-41.

22 Cooper C, Snow S, McAlindon TE, et al. Risk factors for the incidence and progression of radiographic knee osteoarthritis. Arthritis Rheum 2000;43:995-1000.

23 Klunder B, Rud B, Hansen J. Osteoarthritis of the hip and knee joint in retired football players. Acta Orthop Scand 1980;51:925-7.

24 Lindberg H, Roos H, Gärdsell P. Prevalence of coxarthrosis in former soccer players. Acta Orthop Scand 1993;64:165-7.

25 Roos H, Lindberg H, Gardsell P, et al. The prevalence of gonarthrosis and its relation to meniscectomy in former soccer players. Am J Sports Med 1994;22:219-22.

26 Buckwalter JA. Osteoarthritis and articular cartilage use, disuse, and abuse: experimental studies. J Rheumatol Suppl 1995;43:13-5.

27 Videman T. The effect of running on the osteoarthritic joint: an experimental matched-pair study with rabbits. Rheumatol Rehabil 1982;21:1-8.

28 Kiviranta I, Tammi M, Jurvelin J, et al. Articular cartilage thickness and glycosaminoglycan distribution in the canine knee joint after strenuous running exercise. Clin Orthop 1992:302-8.

29 Palmoski MJ, Brandt KD. Running inhibits the reversal of atrophic changes in canine knee cartilage after removal of a leg cast. Arthritis Rheum 1981;24:1329-37.

30 Roos H, Lauren M, Adalberth T, et al. Knee osteoarthritis after meniscectomy: prevalence of radiographic changes after twenty-one years, compared with matched controls. Arthritis Rheum 1998:41:687-93.

31 Armstrong SJ, Read RA, Ghosh P, et al. Moderate exercise exacerbates the osteoarthritic lesions produced in cartilage by meniscectomy: a morphological study. Osteoarth Cartil 1993;1:89-96. 
32 Sharma L, Song J, Felson DT, et al. The role of knee alignment in disease progression and functional decline in knee osteoarthritis. JAMA 2001;286: 188-95.

33 Radin EL, Parker HG, Pugh JW, et al. Response of joints to impact loading - III. J Biomech 1973;6:51-7.

34 Radin EL, Paul IL. Does cartilage compliance reduce skeletal impact loads? Arthritis Rheum 1970;13:139-44.

35 Eckstein F, Lemberger B, Stammberger T, et al. Patellar cartilage deformation in vivo after static versus dynamic loading. J Biomech 2000;33:819-25.

36 Wu JZ, Herzog W, Epstein M. Joint contact mechanics in the early stages of osteoarthritis. Med Eng Phys 2000;22:1-12.

37 Clark AL, Herzog W, Leonard TR. Contact area and pressure distribution in the feline patellofemoral joint under physiologically meaningful loading conditions. J Biomech 2002;35:53-60.

38 Burr DB, Turner $\mathrm{CH}$, Naick $\mathrm{P}$, et al. Does microdamage accumulation affect the mechanical properties of bone? J Biomech 1998;31:337-45.

39 Brown TD, Radin EL, Martin RB, et al. Finite element studies of some juxtarticular stress changes due to localized subchondral stiffening. J Biomech 1984;17:11-24.

40 Gelber AC, Hochberg MC, Mead LA, et al. Joint injury in young adults and risk for subsequent knee and hip osteoarthritis. Ann Intern Med 2000;133:321-8.

41 Graf BK, Cook DA, De Smet AA, et al. "Bone bruises" on magnetic resonance imaging evaluation of anterior cruciate ligament injuries. Am J Sports Med 1993;21:220-3.

42 Felson DT, Mclaughlin S, Goggins J, et al. Bone marrow edema and its relation to progression of knee osteoarthritis. Ann Intern Med 2003:139:330-6.

43 Daniel DM, Stone ML, Dobson BE, et al. Fate of the ACL-injured patient. A prospective outcome study. Am J Sports Med 1994;22:632-44.

44 Lohmander LS, Roos H. Knee ligament injury, surgery and osteoarthrosis. Truth or consequences? Acta Orthop Scand 1994;65:605-9.

45 Brandt KD, Braunstein EM, Visco DM, et al. Anterior (cranial) cruciate ligament transection in the dog: a bona fide model of osteoarthritis, not merely of cartilage injury and repair. J Rheumatol 1991;18:436-46.
46 McDevitt C, Gilbertson E, Muir H. An experimental model of osteoarthritis; early morphological and biochemical changes. J Bone Joint Surg [Br] 1977;59:24-35.

47 Hasler EM, Herzog W, Leonard TR, et al. In vivo knee joint loading and kinematics before and after $\mathrm{ACL}$ transection in an animal model. $J$ Biomech 1998;31:253-62

48 Christina KA, White SC, Gilchrist LA. Effect of localized muscle fatigue on vertical ground reaction forces and ankle joint motion during running. Hum Mov Sci 2001;20:257-76.

49 Mizrahi J, Verbitsky O, Isakov E. Fatigue-related loading imbalance on the shank in running: a possible factor in stress fractures. Ann Biomed Eng 2000;28:463-9.

50 Anderson JJ, Felson DT. Factors associated with osteoarthritis of the knee in the first national Health and Nutrition Examination Survey (HANES I). Evidence for an association with overweight, race, and physical demands of work. Am J Epidemiol 1988;128:179-89.

51 Blair SN. Effects of physical activity on cardiovascular disease mortality independent of risk factors. In Leon AS, ed. Physical activity and cardiovascular health. A national consensus. Champaign, IL: Human Kinetics, 1997:127-36.

52 Penninx BW, Messier SP, Rejeski WJ, et al. Physical exercise and the prevention of disability in activities of daily living in older persons with osteoarthritis. Arch Intern Med 2001;161:2309-16.

53 Petrella RJ, Bartha C. Home based exercise therapy for older patients with knee osteoarthritis: a randomized clinical trial. J Rheumatol 2000;27:2215-21.

54 Ettinger WH Jr, Burns R, Messier SP, et al. A randomized trial comparing aerobic exercise and resistance exercise with a health education program in older adults with knee osteoarthritis. The Fitness Arthritis and Seniors Trial (FAST). JAMA 1997;277:25-31.

55 Birmingham TB, Kramer JF, Kirkley A, et al. Association among neuromuscular and anatomic measures for patients with knee osteoarthritis. Arch Phys Med Rehabil 2001;82:1115-18.

56 Altman RD, Fries JF, Bloch DA, et al. Radiographic assessment of progression in osteoarthritis. Arthritis Rheum 1987;30:1214-25. 